\title{
Task-based Approach in College English Teaching of Digital-based Context
}

\author{
Ling Jiang \\ Public English Department, Harbin Normal University, Harbin, P.R. China \\ Email: ttjulia@163.com \\ Kai Sun \\ School of Management, Harbin University of Science and Technology, Harbin, P.R. China \\ Email: Sunkai75@163.com
}

\begin{abstract}
With the wide employment of modern educational technology, college English teaching is going on a process of replacing traditional educational media with modern ones, which are closely connected with multimedia computers and internet technology to raise its efficiency and quality. However, some problems and challenges still exist in the college English teaching. In order to solve the problems, this article designs a test and collects data to check the effectiveness of the task-based approach within the Internetassisted multimedia in college English teaching. The results show that Linguistic form was analyzed and practiced with task-based approach which may help the learners notice the linguistic problems and try out new language forms and structures, and that Internet-assisted multimedia has been effective in intriguing learners' interests and greatly enhanced their self-esteem.
\end{abstract}

Index Terms - Internet-assisted multimedia, Task-based approach, College English teaching

\section{INTRODUCTION}

College English teaching, as an essential and fundamental part of the education system, has been undergoing with low efficiency (even though teachers have made great effort to improve it). College students, who have studied English for many years, cannot "function" properly in social contexts, so College English teaching reform is imperative. Chinese English teachers are practicing different teaching models with the increasing importance of English in the $21^{\text {st }}$ century.

As an innovative approach, task-based approach (TBA) has become more and more prevalent among the English teaching modes; however, in fact there are still many problems, for example, teachers still act as controllers in classrooms, and tasks in classrooms are language drills or practice, there is seldom communication in classroom, and learners are still passive receivers. Hence, we need to solve the problems by using some new and effective ways to teach. The College English Curriculum Requirements proposes that the modern technology be used in college English teaching so as to change the existing unitary teacher-centered pattern of language teaching.

In modern times the use of computer technology has captivated the attention of the teaching community. Multimedia and network applied in foreign language teaching has been considered to be a more effective medium of foreign language teaching, which represents an inevitable trend of applied linguistics. Over the last few years many schools, colleges and universities in China have experimented with multimedia-based and network-based English instruction. Computer assisted language learning (CALL) is becoming prevalent in foreign language learning and teachers play ever most important roles within this realm. But CALL is still neglected by many teachers and the deficiencies in combining computer with methodology in language teaching led schools and instructors reluctance to the adopt of CALL. In order to fill in the gap of the existing problems in teaching and learning the second language, we need to combine the two factors and conduct research of the theory of constructivism to find a more efficient teaching approach.

\section{LITERATURE REVIEW}

\section{A. The Overview of the Task-based Approach}

i. $\quad$ The History and the Theoretical Basis of the Task-based Approach

Task-based Approach is the latest development results of western English education and also the latest development of the communicative approach, laying stress on learning by doing. Prabhu (1987) firstly advocated that "structure can best be learned when attention is focused on meaning" and "adopts meaningfocused activities" [1]. As the key to TBL approach, the term "task" has been defined in a variety of ways. Task is a piece of work undertaken for oneself or for others, freely or for some reward (Long, 1985) [2]. Nunan (1989) divided classroom tasks into real-world task and pedagogical task [3]. Willis (1996) identified six main types of tasks, including listing, ordering and sorting, comparing, problem solving, sharing personal experiences and creative task [4]. Form the pedagogical perspective, Richard (2000) stressed on language 
knowledge [5]. From the perspective of language learning, Breen (1987) claimed that a task is a basic unit for designing language classroom activity [6]. Most methods are heavily rooted in linguistic theories, theories of learning or theoretical assumptions on the nature of linguistic communication. Vygotsky (1962) thought of language as a social event, a shared social activity within a community [7]. The interaction belongs to the very nature of Language. The functional nature of language is highlighted by Firthian and Hallidayan linguistics. Wilkins (1976) incorporated this functional dimension into methodological issues on language teaching [8]. From that point of view Wilkins' notional-functional syllabus is more synthetic than analytical, as Long and Crookes (1993) claimed [9]. In the process of language acquisition the role of the learner is central and decisive, but it takes place only if knowledge (language) is integrated by the individual into his own set of values and idiosyncrasy and if a linguistic system is built.

As for the theoretical background of TBA, different scholars in China have different opinions. He Anping (2001), Yuan Zhoulin (2001), Ding Wen (2002), Yu Yongnian (2003), Feng Yufang (2004) and Zhang Zhengdong (2004) regard TBA as one particular development within the broader Communicative Approach; however, Yuan Changhuan (2002), Cheng Kela (2003), Liu Fusheng (2003), Qin Xiugui (2004), Xu Xiaoging (2004) and Cai Lanzhen (2004) believe that TBA is one of the new teaching methods which is based on the Second Language Acquisition Theories; Gong Yafu, Luo Shaogian(2003) and Cheng Xiaotang(2004) think that TBA theory came from Language Acquisition Theory and Social Constructionism Theory.

Additionally, some scholars make great contribution to the task design, implementation and evaluation. He Lianzhen (2003), Cheng Xiaotang (2004) and Zhang Haiqing (2004) have explained these three aspects in details. Lu Li (2002), Xu Jin (2002), Ge Wenshan (2003), Wen Rongsheng (2004) and Jia Zhigao (2005) agree that Nunan's (1989) task analyses model is acceptable; but some primary school teachers such as Pan Juhe (2002), Xu Weina (2003), Zhu Yuan (2003), Sheng Yanping (2003) and Li Shuiping (2003) disagree Nunan's task design principle. When mentioned implementation, Ding Wen (2002), On Yang Xueqing (2003), Liu Peiqing (2003), An Wenyi (2003) and Shen Qin (2004) believed that the "task" should be arranged from easy to difficult. Xia Jimei (2003) and Luo Shaoqian (2002) make great effort to solve the problem of the evaluation of TBA.

$$
\text { ii. The Difference Between Task-based }
$$
Learning and the Traditional Way

A traditional model for the organization of language lessons, both in the classroom and in course-books, has long been the PPP approach (presentation, practice, production). With this model individual language items (for example, the past continuous) are presented by the teacher, then practiced in the form of spoken and written exercises (often pattern drills), and then used by the learners in less controlled speaking or writing activities. An alternative to the PPP model is the Test-Teach-Test approach (TTT), in which the production stage comes first and the learners are "thrown in at the deep end" and required to perform a particular task (a role play, for example). Jane Willis (1996), in her book 'A Framework for Task-Based Learning', outlines a third model for organizing lessons.[10] While this is not a radical departure from TTT, it does present a model that is based on sound theoretical foundations and one which takes account of the need for authentic communication.

The main advantages of TBL are that language is used for a genuine purpose meaning that real communication should take place, and that at the stage where the learners are preparing their report for the whole class, they are forced to consider language form in general rather than concentrating on a single form (as in the PPP model). Whereas the aim of the PPP model is to lead from accuracy to fluency, the aim of TBL is to integrate all four skills and to move from fluency to accuracy plus fluency. The range of tasks available (reading texts, listening texts, problem-solving, role-plays, questionnaires, etc) offers a great deal of flexibility in this model and should lead to more motivating activities for the learners. Learners who are used to a more traditional approach based on a grammatical syllabus may find it difficult to come to terms with the apparent randomness of TBL, but if TBL is integrated with a systematic approach to grammar and lexis, the outcome can be a comprehensive, all-round approach that can be adapted to meet the needs of all learners.

Task-based learning can be very effective at Intermediate levels and beyond, and the methodology requires a change in the traditional teacher's role. The teacher does not introduce and present language or interfere or help during the task cycle. The teacher is an observer during the task phase and becomes a language informant only during the language focus stage.

\section{B. An Overview of the Internet-assisted Multimedia Language Teaching and its Theoretical Basis}

\section{i. The History of the Internet-assisted Multimedia Language Teaching}

Computer-Assisted English Language Teaching and Learning (CALL) has mature guidance theories developed by both foreign and domestic scholars for few decades. The present research, which is mainly descriptive in nature, is intended to investigate how learners have been influenced by CALL in the light of motivation, learner autonomy, learning strategies and interactive and cooperative learning.

Computer assisted language learning (CALL) is defined as any process in which a learner uses a computer, and, as a result, improves his or her language (Beatty, 2003).[11] It is interdisciplinary in nature, and "has evolved out of early efforts to find ways of using the computer for instructional purposes across a wide variety of subject areas, with the weight of knowledge and breadth of application in language learning ultimately resulting in as more specialized field of study”(Levy,1997).[12] The development of computer technology has made computer-assisted language learning possible. Pennington(1996)summarizes four 
reasons for the increasing accessibility of computers to human beings: 1) the decrease of size and expense; 2) the increase of software; 3) software design using more attractive and friendly medium; and 4) attitude changes about computers.[13] Computers have been used for language teaching and learning in the world since the 1960s, and according to Warschauer (1996), its history can be roughly divided into three phases shown as Table I: behaviouristic CALL, communicative CALL, and integrative CALL.[14]

TABLE I. THREE PHRASES OF CALL

\begin{tabular}{|c|c|c|c|}
\hline & $\begin{array}{l}\text { Behaviorist } \\
\text { CALL }\end{array}$ & $\begin{array}{c}\text { Communicative } \\
\text { CALL }\end{array}$ & $\begin{array}{l}\text { Integrative } \\
\text { CALL }\end{array}$ \\
\hline $\begin{array}{l}\text { Learning } \\
\text { Theory }\end{array}$ & Behaviorism & $\begin{array}{l}\text { Information- } \\
\text { processing } \\
\text { and } \\
\text { Constructivism } \\
\end{array}$ & $\begin{array}{c}\text { Social } \\
\text { constructivism }\end{array}$ \\
\hline $\begin{array}{l}\text { Linguistic } \\
\text { Theory }\end{array}$ & Structuralism & $\begin{array}{l}\text { Transformational } \\
\text { generative } \\
\text { grammar }\end{array}$ & $\begin{array}{c}\text { A more } \\
\text { semantic } \\
\text { and more } \\
\text { social } \\
\text { view of } \\
\text { language }\end{array}$ \\
\hline $\begin{array}{l}\text { Teaching } \\
\text { Approach }\end{array}$ & Audiolingualism & $\begin{array}{c}\text { Communicative } \\
\text { language } \\
\text { teaching }\end{array}$ & Task-based \\
\hline Computers & $\begin{array}{l}\text { Mainframe } \\
\text { computers }\end{array}$ & Microcomputers & $\begin{array}{c}\text { Computers and } \\
\text { the Internet }\end{array}$ \\
\hline $\begin{array}{l}\text { Principal } \\
\text { Role }\end{array}$ & $\begin{array}{c}\text { To provide } \\
\text { unlimited drill, } \\
\text { practice, tutorial } \\
\text { explanation, and } \\
\text { corrective } \\
\text { feedback. }\end{array}$ & $\begin{array}{c}\text { To provide } \\
\text { language input } \\
\text { and analytical } \\
\text { and inferential } \\
\text { tasks. }\end{array}$ & $\begin{array}{l}\text { To provide } \\
\text { alternative } \\
\text { contexts for } \\
\text { social } \\
\text { interaction: to } \\
\text { facilitate } \\
\text { access to } \\
\text { existing } \\
\text { discourse } \\
\text { communities } \\
\text { and the } \\
\text { creation of } \\
\text { new ones }\end{array}$ \\
\hline
\end{tabular}

The participation of the Internet in modern foreign language teaching has brought great changes to teaching concepts, teaching models, teaching methods and means, and to a still wider range of language teaching and language learning materials. It's a great influence and the challenge should be fully realized and met.

\section{ii. The Advantages and Disadvantages of CALL}

Many researchers have done great research on the effectiveness of CALL, and made many findings on advantages of CALL. The use of CAI (Computer-assisted Instruction) as a supplement to conventional instruction produces higher achievement than the use of conventional instruction alone. Computer-based education (CAI and other computer applications) renders higher achievement than conventional instruction alone. The use of CAI leads to more positive attitudes toward computer, course content, quality of instruction, school in general, and self-learner than the use of conventional instruction alone. The use of CAI is associated with other beneficial outcomes, including greater internal locus of control, school attendance, motivation time-on-task, and student- student cooperation and collaboration that the use of conventional instruction alone. CAI is more beneficial for younger students than elder ones. CAI is more effective for teaching lower cognitive material than highercognitive material. Students' fondness for CAI activities centers on the immediate, objective, and positive feedback provided by these activities. (Kathleen Cotton, 1991)[15] Furthermore, CALL activities may be based in a network, such as the Internet, presenting several advantages: rapid global access at any time from any computer with Internet access; integration graphics, audio, and text; and ease and low cost of publication. (Kern \& Warschauer, 2000) [16] In sum, network-based simulations offer access to an otherwise unattainable environment that translates into language input and tasks for second language students.

As CALL is concerned, most researchers would agree that in the hands of skilled language teachers and learners, the potential of CALL is enormous. But several investigators have reported various deficiencies in the few empirical studies addressing the pedagogical benefits of CAI on learning. (Reeves, 1993) [17] Schmitt has noted the following four major research design flaws: small sample sizes, lack of criteria for what constitutes appropriate software, faulty statistical analysis, and inadequate length of treatment to measure education outcomes. Reeves claims three distinct stages: research on the effect of computer literacy, research specific types of applications, and finally, research on the analysis of learner control variables.

Such a series of negative evaluations from recent years does not justify the conclusion that computer should be excluded from foreign language teaching and learning. On the contrary, it is essential to concentrate on the above mentioned specific advantages of the computer in order to employ this new medium in accordance with its potential. Until now, many CALL activities were created with the sole rationale that computers are useful and motivating for students, although such activities lacked a solid research base. Recently, however, the field of CALL has begun to undergo self-evaluation, and researchers are now claiming that in order for the field to progress, it is necessary to look to SLA principles that make language teaching effective. (Chapelle, 1998) It is our teachers' task to find appropriate ways make good use of technology in our language teaching practice. [18]

\section{iii. The importance of the Internet-assisted Multimedia Language Teaching}

Computer technology has been used in education for more than forty years. The popularization of modem multimedia personal computers provides technological assurance for the progress of foreign language teaching. And the Internet not only offers greatly expanded opportunities for language learners to communicate with native speakers or others promptly and inexpensively; but also offers access to the most update and abundant information throughout the world. Many CALL educators place greater emphasis on language use in authentic social contexts and integrate various language skills and computers more fully into language learning process. In a 
CALL EFL classroom, the role of technology is to support, enhance and facilitate the learning process. Debski (1997) proclaims that it is used to enrich the language classroom through fostering human to human communication and creative endeavor, and build environments in which learners could learn through exploration and experience[19]. In a network environment, students are given much independence and responsibility for their own study. The teacher's main role is to explain objectives, introduce materials and procedures, and monitor the learning process. Thus, in network-based learning, students have a great control over their learning while the teacher is a kind of facilitator. This is the ideal learning environment.

With the increased use of modern communication technology such as e-mail, forum and cooperative approaches to learning, especially in CALL environment, the notion of leaner independence has aroused teachers and researcher's attention. In a traditional classroom, it is always dominated by the teacher, so the learner's autonomy is not often encouraged. The teacher seems to control everything in a class, such as learning materials, learning tasks and the pace of a lesson. However, different learners have different paces, which probably will be different from the paces arranged by the teacher. In CALL environment, learners can work at their own paces. They can spend more time on those difficult questions and they can choose to learn materials that interests them. Information in CALL environment can be reviewed and tasks can be repeated again and again until the learner has finally accepted the knowledge and eager to move on to a new topic. Apart from that, CALL environment provides learners with a great deal of tailored learning materials that better meet the individual learners' own needs and enable them to make a better control of their learning. Various learning software even provides students an authentic learning environment in a virtual form in their program, which greatly stimulates the students and makes them be a real centre in the process of task-taking.

\section{ANAlysis of the Present Situation of Foreign LANGUAGE TEACHING AND LEARNING}

\section{A. The Present Situation of the TBL in China}

In China, Xia (1998) et al, at Zhongshan University, initially did the research on TBL. [20] They introduced and analyzed the essence of TBL, believing TBL means that language teaching should be closely related to the real world and classroom teaching reflects society. Language learning should not be only language practice but method learning. The goal of the language teaching is not only to learn language but to develop the students' cognitive ability with the means of the language. Meanwhile, Zhang (1998) analyzes the theoretical bases, the scope and the advantages and disadvantages of TBL Syllabus [21]. In 2000, Cheng pointed out TBL syllabus should combine the process syllabus with tasks in China [22].
In 2001, TBL was put forward by Educational Commission to challenge the traditional language teaching. TBL began to be widely used and developed greatly in primary and secondary school. But problems still existed, such as the task in every class takes the same model or the task-based teaching means learning by students themselves. If learning is stressed and doing is looked over, learning will be only for learning's sake. That is the traditional teaching model. On the other hand, if doing is stressed and learning is ignored, doing will be only for doing's sake, which still cannot be called the task-based teaching. Besides, how to practice task-based approach to College English teaching has seldom been discussed so far.

\section{B. Analysis of the Present Situation of the Application of the Internet-assisted Multimedia}

Many universities in China have set self-access centre which are equipped with computers, Internet resources and many multimedia learning materials such as CDROMs, videotapes and Satellite TV, providing students with an autonomous learning environment. They are allowed to make use of the self-access centre as part of their English courses. And there is always a teacher on duty as a counsellor in the self-access centre to give the students help during their self-learning process. This kind of computer assisted self-access language learning centre makes great enhancement on learner's self-access learning ability. In a CALL classroom, teachers will use computer to replace old-fashioned chalk and blackboard. More active, sometimes even interactive courseware will be presented to learners. Unquestionably, to learners, it is more vivid and interesting to use the highlighted key points and flickering mouse arrow to support traditional teaching. At present, due to its convenience and adaptability to both single computer and the Internet, more and more teachers choose to develop web page courseware. Thus learners can jump to any page they want to read. Language learners may also increase their interests through use of combined media. For example, use of video or animation, supported by subtitles, with instantly available definition language items, and by online tasks with synchronous feedback may motivate learners to attend class because such learning supports may make the input more comprehensible. These learning supports may also motivate some learners to "notice", and consequently increase their awareness of the linguistic features of the input instead of the grammar points, and to put it into practice as more as possible.

However, there are also problems in learning in the CALL environment. As a matter of fact, language learners are often overwhelmed by the enormous information applied by the various learning materials on the Internet or multimedia. They do not know what is more useful and better fit for their study. Victori and Lockhart (1995) report that many learners perceive selfaccess centres just as a resource for materials (e.g. grammar texts, novels, videos and computers) rather than a place where they can fully develop their language learning skills.[23] 


\section{Problems in Applying a Task-based Approach in Chinese Educational Context}

Lots of students learn English just because English is a compulsory subject. Getting a good mark is the most important consideration for students. Very few students enjoy English for the reason they want to integrate into the culture of its speaker. It is not difficult to find that the students in those schools are not highly motivated, for their motivation is instrumental, not integrative. The second obstacle is the teachers who are non-native speakers. Their low level of academic in language teaching may reflect this deficiency. As Willis (1996) said that "the exposure and input come from teacher talk, especially during the pre-task phase and when reviewing language analysis" a demand on the teachers and makes most of them.[24] Obviously this makes feel frustrated. Except for this, the teachers are supposed to control practice and make sure that as many learners as possible participate in the class.

In order to overcome the current problems of English language teaching in China, TBL seems to be a promising path to pursue. The reasons are that it is premised on the theoretical view that instruction needs to be compatible with the cognitive processes which was ignored by the traditional Grammar-Translation Approach, that teachers can keep up with developments in English teaching methods outside China by introducing TBA, and that TBL can create more ideal situations for language learning within the Chinese context. According to Kasper (2005), real-world materials which are introduced in task-based classrooms, can foster students' pragmatic competence, especially regarding cultural reflections.

\section{RESEARCH DESIGN}

\section{A. Study Aim}

The study is designed to check the effectiveness of the task-based approach within the Internet-assisted multimedia in the process of teaching the College English. To be exact, the author wants to find the result that the task-based approach will be proved to be effective on the improvement of the student's grasp of the context. It is hypothesized that task-based approach through Internetassisted multimedia can function positively in reforming the teaching and learning situation in China's college English teaching and learning.

\section{B. Subjects and Procedures}

To find out a more suitable teaching approach for Chinese students in college, an investigation was made firstly to understand the situation of English teaching. And the research mainly focuses on the teaching approach. 25 college English teachers are asked to do the questionnaire.

The author has chosen 128 freshmen of different departments in Harbin Normal University with similar scores of entrance exam and divided them into two classes equally. Class 1(experimental group) have undertaken an " $3+1+x$ " teaching model, which still requires the students to learn automatically by using the campus-wide language learning platform after class besides the 3 classes of the intensive reading and 1 class of listening; Class 2 (unexperimental group) have attended in regular lessons. The study was conducted in the winter and summer semesters between 2009 and 2010 . The students of Class 1 learn with Internet-assisted multimedia once in a week for free, two hours for each time. Besides, they regularly have learned the materials provided by the Campus-wide Language Learning Platform several times for self studying in the lab. During this learning process, teacher used different ways to facilitate learner motivation, encouraged autonomous learning and interaction \& cooperation between learners, and trained them in basic knowledge of learning strategies. In order to test the efficiency of the TBL within the context of we collected the two termexamination data. At the end of the second term, in order to find out our students' general attitudes toward the new approach use, several question items were designed to elicit the subjects' responses.

\section{DAta AnAlysis AND Discussion}

This study was implemented to determine the effects of combining Task Based Approach with the Internetassisted Multimedia on learners' learning proficiency. The final results on the subject-two classes of Harbin Normal University will be analyzed, and discussions are presented on the statistical results.

\section{A. Test Score Analysis and Discussion}

\section{i. $\quad$ Test Score Analysis}

The results for the comparison of the final scores of the two groups (experimental vs. unexperimental) are presented in Table II as following:

TABLE II. THE FINAL SCORE IN TWO TERMS

\begin{tabular}{|c|c|c|c|c|}
\hline \multicolumn{3}{|c|}{ Class 1 } & \multicolumn{2}{c|}{ Class 2 } \\
\hline & Mean & $\begin{array}{c}\text { Standard } \\
\text { deviation }\end{array}$ & mean & $\begin{array}{c}\text { Standard } \\
\text { deviation }\end{array}$ \\
\hline First term & 68.38 & 9.45 & 65.7 & 7.92 \\
\hline $\begin{array}{c}\text { Second } \\
\text { term }\end{array}$ & 84.9 & 4.22 & 78.6 & 7.86 \\
\hline
\end{tabular}

As mentioned above, Class 1 and the Class 2 were at the same level at the beginning of the research. However, in the first term, Class 1 scored a little better than Class 2 but no significant difference could be found from the mean score (68.38 V.S. 65.7). But in the second term, Class 1 scored significantly better than Class 2. (84.9 V.S.78.6). From standard deviation, we come to the conclusion that during short-term CALL instruction, TBL lessons were effective only to some of the students (Class1 standard deviation $=9.45$, Class 2 standard deviation =7.92). But in the long run, things changed greatly. After a year of CALL instruction, significant difference in scores was consumedly shortened. The highest score of the student in the two classes (individual student highest score in class $1=93$, class $2=90$ ) shows that TBL lessons with CALL components are beneficial with those high achieving students. The lowest score of the individual student in Class 1 was 77, but that of Class 
2 was only 60, there is great difference here, this testified that TBL lessons within the context of CALL is more beneficial with lower-achieving students than with higher-achieving ones. On the whole, from the two terms results, we may definitely come to the conclusion that the application of task-based approach is more effective than traditional teacher-directed approach within the context of CALL.

\section{ii. Discussion}

Learners in the experimental group are involved in eighteen weeks of communicative tasks under the new Internet-assisted multimedia environment. In order to accomplish the tasks, the learners in the experimental group cooperated with each other and turned out meaningful production. Interactive and positive learning was achieved. The learners were fully exposed to authentic input and output, which contributed a lot to the intake of the target language and to modify their interlanguages. Linguistic form was also analyzed and practiced at the last stage of the task which may help the learners to notice the linguistic problems and to try out new language forms and structures.

Then they could not study efficiently, thus improved slowly. In the conventional teaching to the unexperimental group, the input was only the textbooks and the formal instruction from the teacher. The knowledge about the language was stable, separated from context. Actually the use of the language in real scene should be global, dynamic and context dependent. Meanwhile, the learners in the conventional class had no chances to explore the language and to check their hypothesis about the language. Then they were actually not very clear about their own weakness in language acquisition, thus could not study efficiently, thus improved slowly.

\section{B. Analysis of the Questionnaire for the Students}

The questionnaire, was arranged in the following angles: learner's motivation, autonomy, learning strategies, and interactive\& cooperative learning, etc. They were purposefully arranged in a random order. Nine questions are answered on a five-point scale which is strongly disagree, disagree, neutral, agree and strongly agree. The questions and their findings are shown in Table III.

According to the findings of questionnaire, we can find that the students have become quite familiar with the life with computers, that is, they have become much more confident and joyful for this kind of life, with the help of the Internet-assisted multimedia. It is many causes that lead to the change. Firstly, the long-distance sometimes even cross-cultural network communication as helped sustain their interests. This kind of communication has increased learners' awareness of being members of a global village. When they get familiar with some of the Western customs and other cultural activities from those foreign net pals, they just feel even more interested in communicating with them. At the same time, the information they acquired will appear to be more vivid and more impressive compared with that they learnt from dull textbooks. Secondly, computer-networks have also helped provide a more easy-going communicative environment. With the aid of computers and the Internet, learners can publish, revise, move or delete any part of their own language performance conveniently. Thirdly, through the program, the learners have been empowered to control their learning. It is them instead of the teachers who decide what to learn and how to learn. This empowering nature of CALL environment pushes them to work responsibly. Fourthly, the students have become more and more independent in the learning activity. Actually, the training of learners' sense of responsibility has been successful, their deep-rooted traditional concepts have been gradually changed. Therefore, they can access the extensive information they want freely. This implies that after the program, learners are aware of the importance of choosing learning materials with an adequate difficulty to their own level.

TABLE III. THE SUMMARY OF THE QUESTIONNAIRE DATA FOR STUDENTS USE

\begin{tabular}{|l|c|}
\hline \multicolumn{1}{|c|}{ Questions } & Finding \\
\hline $\begin{array}{l}\text { I. feel more confident and } \\
\text { comfortable to join discussion via } \\
\text { computer. }\end{array}$ & $\begin{array}{c}\text { Agree } 65 \% \\
\text { Disagree } 35 \%\end{array}$ \\
\hline $\begin{array}{l}\text { I enjoy using Internet to } \\
\text { communicate in English with } \\
\text { people around the world. }\end{array}$ & $\begin{array}{c}\text { Agree } 55 \% \\
\text { Strongly agree } 14 \% \\
\text { Disagree } 31 \%\end{array}$ \\
\hline $\begin{array}{l}\text { The way of learning "College } \\
\text { English" course in CALL } \\
\text { interest in communicating in }\end{array}$ & Agree $70 \%$ \\
English. & Disagree $30 \%$ \\
\hline $\begin{array}{l}\text { The courseware my teacher has } \\
\text { used helps me understand the text } \\
\text { better. }\end{array}$ & Strongly agree $21 \%$ \\
5. I've taken more responsibility for \\
my own learning in the Internet \\
Classroom.
\end{tabular}

\section{Analysis of the Questionnaire for the Teachers}

Based on the questionnaire, the questions are designed to learn about the present teaching method of the college English for the teachers from the Foreign Language Department of Harbin Normal University. The following data collection was carried out from May to June, 2010.

Table IV shows clearly about the findings of the questionnaires for teachers use. It can be summarized as the followings: most teachers think that the task-based approach has superseded the communicative approach. They believe that an English textbook was a major 
reliable source from which a student learns English. The communicative approach has not been accepted by most English teachers, the English teaching in their class is not dominated by the traditional grammar-translation English method and Audio-lingual method. Teachers have already agreed with the ideas that language learners need opportunities for language use. With the initiation of the communicative approach, the teachers begin to realize the importance of enabling their students to use English. For some reason, they can not apply the communicative approach in their teaching, so they prefer task-based approach which integrates formal and communicative activities. Also, their students like to focus on the words and grammatical structure. The result of this statement indicates that the Chinese Students' learning style and habits in language learning are: a keen interest in an exact understanding of every word, a low tolerance for ambiguity, and a focus on discrete grammar points and specific syntactical constructions. And this is also the obstacles in applying the task-based approach in Chinese educational context.

TABLE IV. THE SUMMARY OF THE QUESTIONNAIRE DATA FOR TEACHERS USE

\begin{tabular}{|c|c|}
\hline Questions & Findings \\
\hline $\begin{array}{c}\text { 1. You know a lot about task-based } \\
\text { approach. }\end{array}$ & $\begin{array}{c}\text { Agree } 86 \% \\
\text { Disagree } 14 \%\end{array}$ \\
$\begin{array}{c}\text { primary } \\
\text { for the language teaching. }\end{array}$ & $\begin{array}{c}\text { Agree } 61 \% \\
\text { Disagree } 39 \%\end{array}$ \\
\hline $\begin{array}{c}\text { 3. Your students like to focus on word } \\
\text { and grammatical structures. }\end{array}$ & Agree $68 \%$ \\
\hline $\begin{array}{c}\text { 4. There are many communicative } \\
\text { activities based on the situation in the } \\
\text { students' real life in your class. }\end{array}$ & Disagree $32 \%$ \\
\hline $\begin{array}{c}\text { 5. You teach English mainly using the } 39 \% \\
\text { Audio-lingual method. }\end{array}$ & Disagree $61 \%$ \\
\hline $\begin{array}{c}\text { 6. You teach English mainly using the } \\
\text { grammar-translation method. }\end{array}$ & Agree $7 \%$ \\
\hline $\begin{array}{c}\text { 7. You teach English mainly using the } \\
\text { Task-based approach. }\end{array}$ & Agree $24 \%$ \\
Disagree $76 \%$ \\
\hline $\begin{array}{c}\text { 8. The main purposes of your students } \\
\text { have been learning English is to pass } \\
\text { the examinations }\end{array}$ & Agree $88 \%$ \\
\end{tabular}

\section{CONCLUSION}

We need to involve students in thinking dependently the whole process of the language learning. The teaching activity should create opportunities for students to try out different skills and interaction and negotiation through group work. By encouraging students to learn from other classmates and authentic tasks, we are helping them to consider for themselves what leads to their success and failure in language using. They should make better decisions about how to improve their language using practice. Hence, the teacher is not only source of information any more, but acts as facilitator so that students can actively interpret and organize the information they are given, fitting it into prior knowledge. The teachers should seek new ways to create an effective environment for language learners to learn. Combining the task-based approach with the college English teaching under the Internet-assisted multimedia environment, we can find that the language learners, the cognitive key role in the learning activity, have exerted their power sufficiently. Considering the multimedia as the cognitive tool, the language learners could take part in the teaching communicative activity actively and positively; they can look for, find and understand the knowledge by themselves; what's more, they can even grasp and apply what they had learnt to practice and become explorers and creators of language rather than passive recipients of it.

\section{ACKNOWLEDGMENT}

The authors wish to thank Professor Shimin GU who reviewed the early version of this paper and gave us many good suggestions. And this work was supported in part by a grant from Special Project of National Education Science Planning (GPA105007), Excellent Group of Humanities and Social Science and Project of High Education and Teaching Reform in Harbin Normal University.

\section{REFERENCES}

[1] N.S. Prabhu, Second language pedagogy. Oxford: Oxford University Press, 1987

[2] M. H. Long, Crookes, A role for instruction in second language acquisition: Task-based language teaching. Clevedon: Multilingual Matters, pp.77-99, 1985.

[3] D. Nunan, Designing Tasks for a Communicative Room. Cambridge: Cambridge University Press, pp. 56, 1989.

[4] J. A. Willis, Framework for Task-based Learning. London: Longman, 1996.

[5] J. C. Richards, The context of language teaching. Beijing: Foreign Language Teaching \& Research Press, 2000

[6] M. Breen. Learner contributions to task design. NJ: Prentice-Hall, 1987.

[7] L. Vygotsky, Thought and Language. Cambridge, MA: MTT Press, 1962

[8] P. Wilkins, Notional syllabus . Oxford: Oxford University Press, 1976

[9] G. Crookes and S. Gass, Tasks and Language Learning: Integrating Theory and Practice. Clevedon: Multilingual Matters, 1993.

[10] Willis, J. A Framework for Task-Based Learning. Longman, 1996.

[11] Beatty, K. Teaching and researching computer-assisted language learning. Essex: Pearson Education Limited, 2003

[12] Levy, M. Computer-assisted language learning: Context and conceptualization. Oxford: Clarendon Press, 1997

[13] Pennington, M. C. The power of CALL. Houston: Athelstan, 1996

[14] Warschauer, M. (1996). Computer-assisted language learning: An introduction. In Fotos S. (Ed.), Multimedia language teaching. Tokyo: Logos International: 3-20. Retrieved Oct. 5, 2008,

[15] Cotton, Kathleen. ComputerAssisted Instruction. Regional Educational Laboratory, School Improvement Research Series, May 1991

[16] Kern, R.,\&Warschauer, M.Theory and practice of networkbased language teaching. In M.Warschauer\&R. Kern 
(Eds.), Network-based language teaching: Concepts and practice. New York: Cambridge University Press. pp.1-19, 2000

[17] Reeves, T Pseudoscience in computer based Instruction: The Case of Learner Control Research. Journal of Computer Based Instruction, 20(2), pp.39-46, 1993

[18] Chapelle, C. and J.Jamieson. ComputerAssisted Language Learning as a Predictor of Success in Acquiring English as a Second Language. TESOL Quarterly 2Q,1, pp.2746,1986

[19] Debski. Beyond the screen: Situating technologymediated language learning .ON-CALL, vol 2, pp. 27-33, November 1997

[20] Xia Jimei and Kongxian. Comparison Between The Models And The Theoretical Bases Of Problem Solving Method And Task-Based Teaching Method, Foreign Language World, August 1998

[21] Zhang Chunxing, Educational Psychology, Hangzhou: Zhejiang Educational Press,1998

[22] Cheng Kela. A Study of Task-based Approach in Foreign Language Learning on Technology, Media in Foreign Language Instruction, pp.10-1, June 2003

[23] Victori, M.\&Lockhart, W. Enhancing metacognition in self-directed language learning.system, 23(2), pp.223-224. 1995.
[24] Willis, J. A Framework for Task-based Learning [M]. London: Longman, 1996.

Ling Jiang was born in Harbin in 1977. Ling got her bachelor and master degree of English language and literature respectively from Northeast Forestry University in 2000 and Harbin Normal University in 2005, both of which located in Harbin of P. R. China.

She works as a Lecturer in Public English Department of Harbin Normal University. And she has published more than ten articles in journals and co-authored three books. And her research interest is the acquisition of second foreign language.

Kai Sun was born in Harbin in 1975. Kai got his bachelor and master degree of business administration respectively from Jilin University of Changchun City in 1998 and Harbin University of Science and Technology of Harbin City in 2004. And Kai was awarded management doctor degree by School of Management of Harbin Institute of Technology in 2009.

$\mathrm{He}$ works as an Associate Professor in School of Management in Harbin University of Science and Technology. He has published more than twenty articles in journals and coauthored two books. And his research interest is management of technology and higher education management. 